\title{
1. The horn that didn't toot: The surprisingly weak relationship from advertising to CSR
}

Shawn Pope

\section{INTRODUCTION}

One of the enduring questions in the literature on corporate social responsibility (CSR) is - why do companies engage in CSR? As with most highly generative research questions, at the center of this one is a contradiction: companies are, ostensibly, profit motivated and, yet, CSR is activity that (often by definition) is not profit oriented, but directed toward increasing social welfare. While inquiry into this puzzling research question has spawned complex conceptual models that put forward myriad CSR motivations at multiple levels of organizational analysis (e.g., Aguilera et al., 2007), the answers in general tend to carry two themes: strategy and politics (Pope, 2015; Pope and Meyer, 2016).

Regarding strategy, the most active and well-developed line of CSR inquiry concerns the idea that CSR is ultimately profitable. Because CSR is, according to numerous surveys, demanded worldwide by the general public (e.g., Hiscox and Smyth, 2006; Mohr and Webb, 2005), researchers have inferred and often documented that many stakeholder groups will reward businesses for CSR. For example, consumers might have a higher willingness to pay for CSR products (De Pelsmacker, Driesen, and Rayp, 2005; Hustvedt and Bernard, 2008); employees might be more motivated to work for CSR companies (Meister, 2012; Raub and Blunschi, 2013); and governments might allow more self-regulation to companies in industries with institutionalized CSR frameworks (Delmas and Montiel, 2008; Vogel, 2010).

With regard to power, theorists with a conflict-theory orientation have suggested that because (genuine, substantial, effective) CSR is inherently very costly and, perhaps further, because consumers do not give nearly as much purchasing support to CSR-practicing companies as they claim to do in surveys (Dahlmann, Brammer, and Millington, 2008; Eckhardt, Belk, and Devinney, 2010; Vermeir and Verbeke, 2006), CSR must therefore be imposed upon corporations from the outside through strategic stakeholder activism (Katz, 2010; King and Soule, 2007; Soule, 2009). Indeed, numerous tactics have been observed by which stakeholders have successfully pushed companies to adopt CSR. Activists have constructed and promulgated new CSR organizational rankings (Muli, 2013; Scalet and Kelly, 2009) and utilized online media platforms to shame laggards (Cho and Hong, 2009), as well as drawn upon more traditional tactics such as boycotts and the filing of shareholder resolutions at companies' annual meetings (O'Rourke, 2002; Reid and Toffel, 2009). More generally, conflict theorists are likely to construe CSR as 'essentially a contested concept' (Okoye, 2009) and to perceive the contemporary CSR field as a 'political settlement' among companies and their loyal opposition, a hard-fought outcome in which none of the parties have acquired all the concessions they would have wished (Bartley, 2007a).

Turning to the specific argument of the current chapter, both strategic and political 
accounts of CSR mutually reinforce one another in the expectation of a positive relationship from advertising to CSR. Strategic accounts expect such a relationship because they envision CSR as a tool for companies to differentiate themselves or their products from the competition. A relationship with advertising is often suggested because the companies that are the most likely to use CSR for differentiation purposes are thought to be those that are in highly competitive industries or those that are sensitive to emerging consumer demands for CSR (both of which can also be proxied by the degree of advertising intensity). The usage of CSR for branding purposes, which is thought to be very widespread, ties into contentious debates about whether the modern CSR movement is merely a branding exercise on the part of large, consumer-oriented multinational companies, and therefore a movement that is incapable of generating true social change beyond the narrow economic interests of these firms (Alves, 2009; Pope and Wæraas, 2016; Soederberg, 2007).

Political theorists, for their part, tend to expect a relationship from advertising to CSR based on a different logic. This is that firms with high advertising have higher public visibility and thus are more subject to the activist pressure that is thought to have ushered in the contemporary CSR movement. Activists, according to this logic, are highly strategic but resource strapped. They purposefully direct their energies to winning highly symbolic CSR victories from the most visible companies. Such symbolic victories may resonate with the general public and be amplified through media coverage. Highly visible companies, of course, may anticipate this dynamic and engage in CSR preemptively. Otherwise, as a function of the extensive market research that precedes their advertising campaigns, these companies may simply be more attuned to external stakeholder preferences and demands, which are increasingly for CSR.

Taking justification from both logics, over 30 empirical studies that I gather, array, and assess later in this chapter have attempted to establish a relationship from advertising to CSR. These studies, surprisingly, have struggled to do so. This is despite the ascendance of the strategic and political logics of CSR motivation that, together, mutually reinforce the expected relationship. By collecting and evaluating this growing literature, I hope to provide some clues for future researchers seeking to refine this literature by asking when and where the relationship from advertising to CSR will be positive, rather than assuming a general relationship. It is becoming clearer, in this regard, that future research will need to elaborate new theoretical angles to have a better chance of detecting the relationship, or else, abandon the search in favor of alternative explanations that feature moral, ethical, normative, or institutional accounts of CSR motivation; accounts that do not hinge on the expectation of advertising expenditures before or after CSR adoption.

The second contribution of the chapter is to add original quantitative evidence to this research area. The chapter conducts its own panel study of the relationship from advertising to CSR. The panel study is notable for having a sample that is international, for its efforts to increase statistical power by collating advertising expenditures from several financial databases (a variable that is notorious for having excessive missing values), and for its parsimonious model estimation to increase as much as possible the chance of detecting a small relationship. This original study, as well, fails to provide robust evidence in favor of an advertising-to-CSR relationship. The study ends with a rounded discussion of the findings of the literature review and panel study to direct future scholars toward more promising lines of inquiry. 


\section{Key Terms}

Key terms are used in this chapter in a manner that is consistent with conventional definitions. CSR refers to '[a]ctions that appear to further some social good, beyond the interests of the firm and that which is required by law' (McWilliams and Siegel, 2001, p. 117). This common definition features 'actions,' but CSR may relate to statements, policies, and reports, which are not actions as much as official, aspirational, or discursive representations. Thus, throughout this chapter 'CSR activity' (or just 'CSR') subsumes CSR actions, discourse, adoption, and other forms of CSR activity. Since there are debates about the general quality of contemporary CSR practices, it is necessary also to define CSR performance. CSR performance is the perception of high-quality, effective, or substantive CSR as assessed by an absolute standard or relative to company peers (Brower and Mahajan, 2013; De Quevedo-Puente, De La Fuente-Sabaté, and Delgado-García, 2007; Waddock and Graves, 1997). CSR performance is measured in this chapter by the Thomson-Reuters ASSET4 ratings, which are comprehensive, long-standing, companylevel, continuous measures of CSR performance at the international level. 'Advertising' is 'any message or other programming material which is broadcast or otherwise transmitted, published, displayed or distributed in exchange for any remuneration, and which promotes or markets any company, service, facility or product' (Ligos and Guritz, 1994, quoting from the US Internal Revenue Service Prop. Reg. 1.513-4[b]). In an influential typology, advertising has been dichotomized into the modes of information dissemination and persuasive appeal (Santilli, 1983). Advertising as information dissemination involves the spread of objective, verifiable information about company practices and product attributes (Nelson, 1974). Advertising as persuasive appeal involves the use of suggestion, rhetoric, or visual discourse to link corporations or their products to 'power, wealth, and status,' or to other desirable qualities such as generosity, creativity, or moral probity (Crisp, 1987, p. 413). Advertising levels are measured later for sample companies rather straightforwardly as advertising expenditures reported on financial statements or gathered through special surveys by a leading trade group in the advertising industry.

\section{PREVIOUS RESEARCH}

There are 32 regression-based studies that test a relationship from advertising to CSR, according to my query of the Google Scholar database primarily with the search terms 'CSR' (or 'philanthropy') and 'advertising intensity' (or just 'advertising'), followed by a search for additional qualifying studies appearing in the citation trees of the preliminary search results. Table 1.1 arrays the final search results by their methodological features, such as observation windows, codings of advertising, and general findings. As a general summary, this body of literature tends to find that the relationship from advertising to CSR is positive, but insignificant. Only about a third of this literature (11 studies) is able to document a significant relationship from advertising to CSR. The confirmatory studies, it should be noted, have several methodological limitations. About half are cross-sectional, rather than longitudinal, and about half predict philanthropic giving, rather than general CSR performance. There are no studies that attempt to rule out endogeneity, although the diagnostic tests of one of the studies finds that the relationship is potentially endogenous 


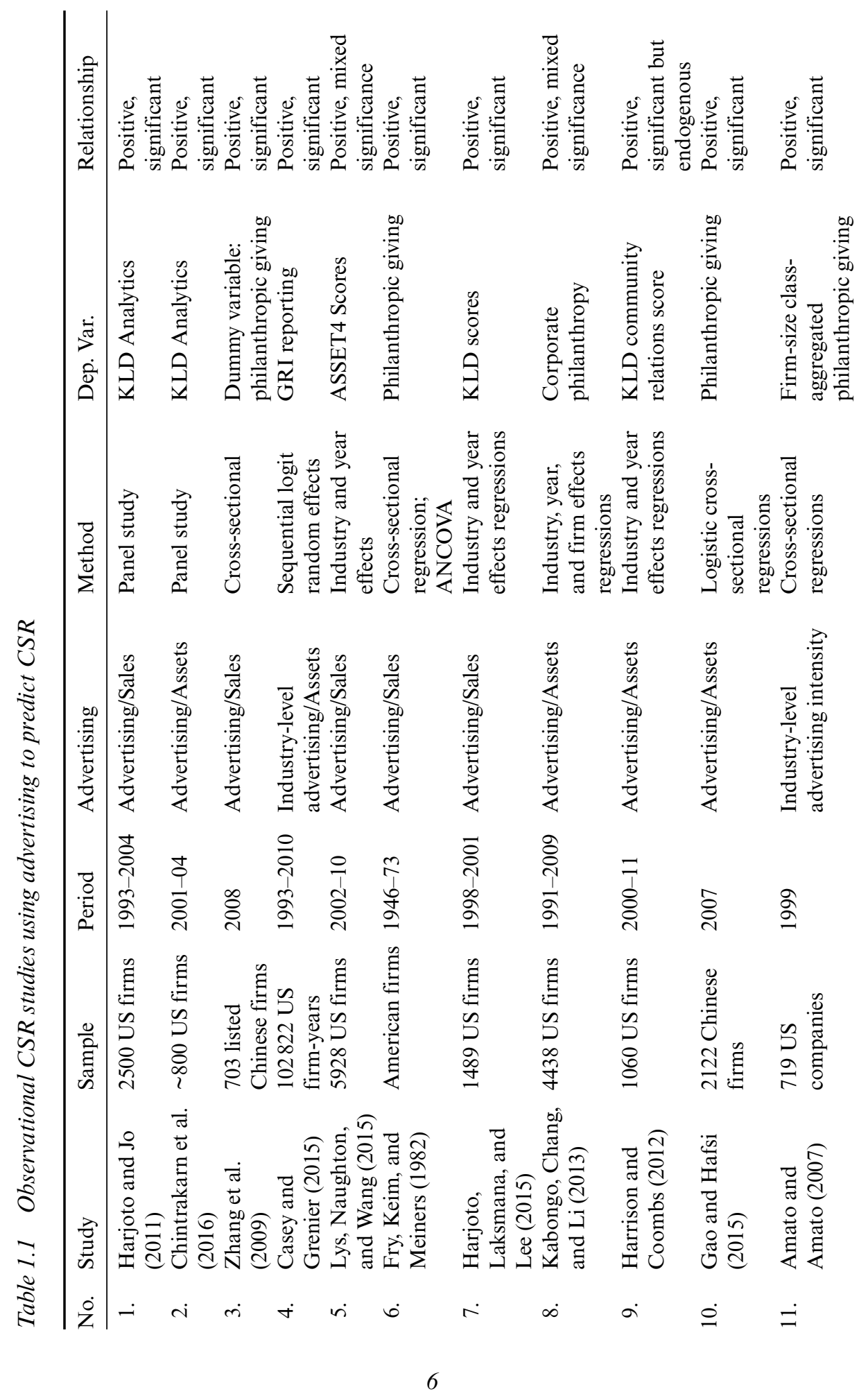




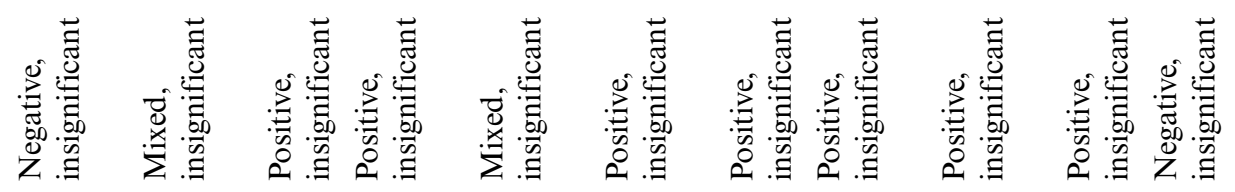

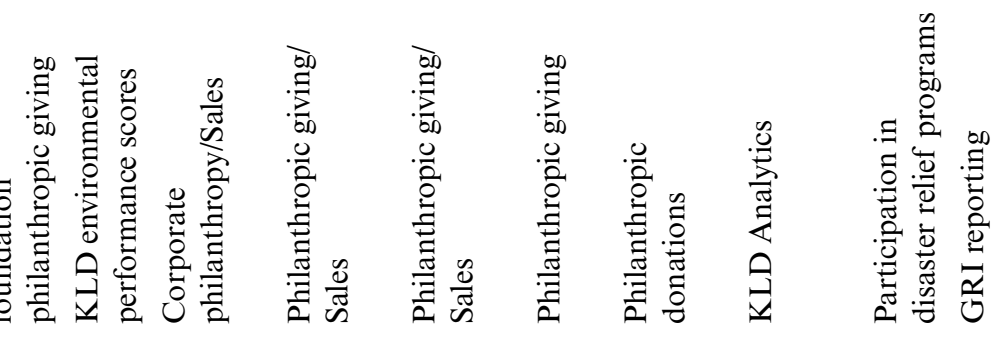

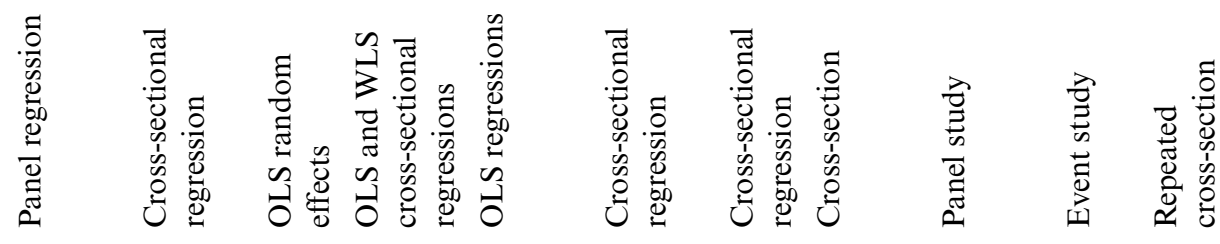

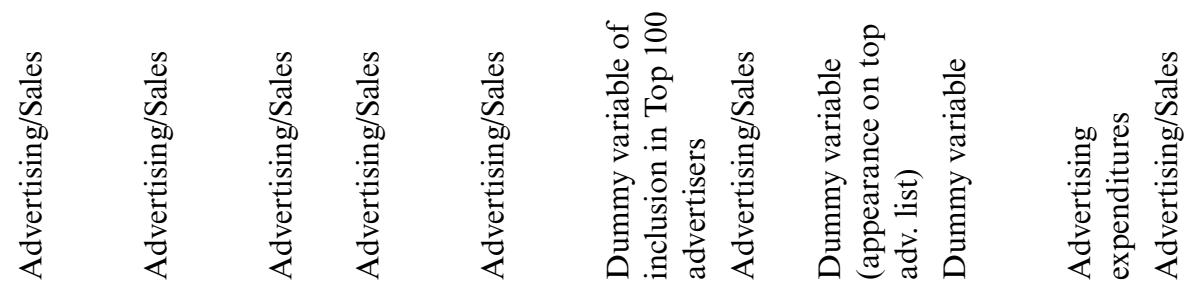

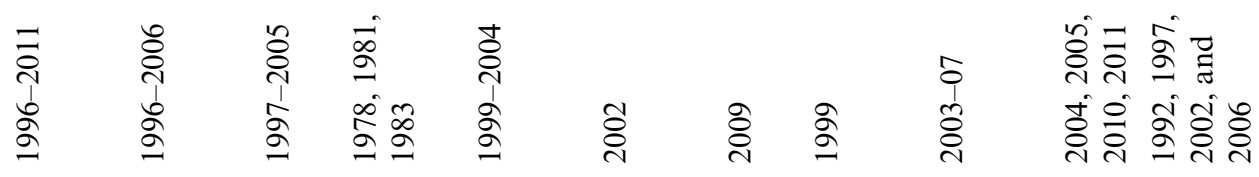

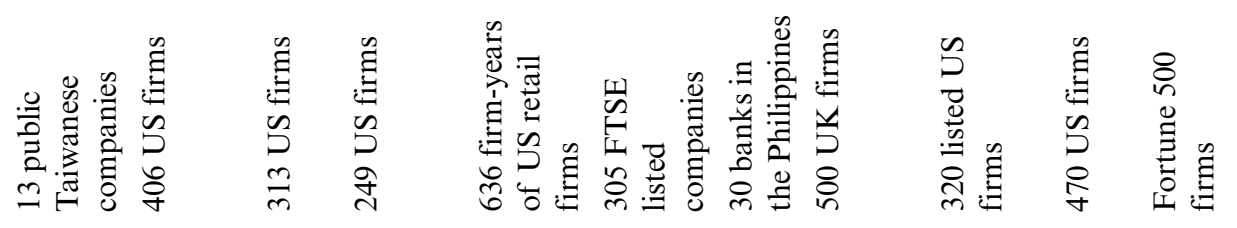

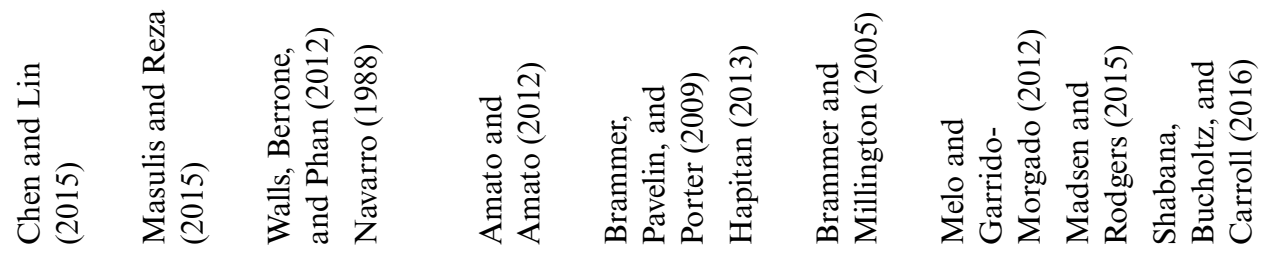

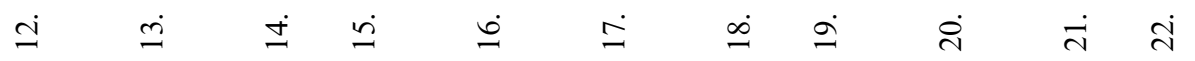




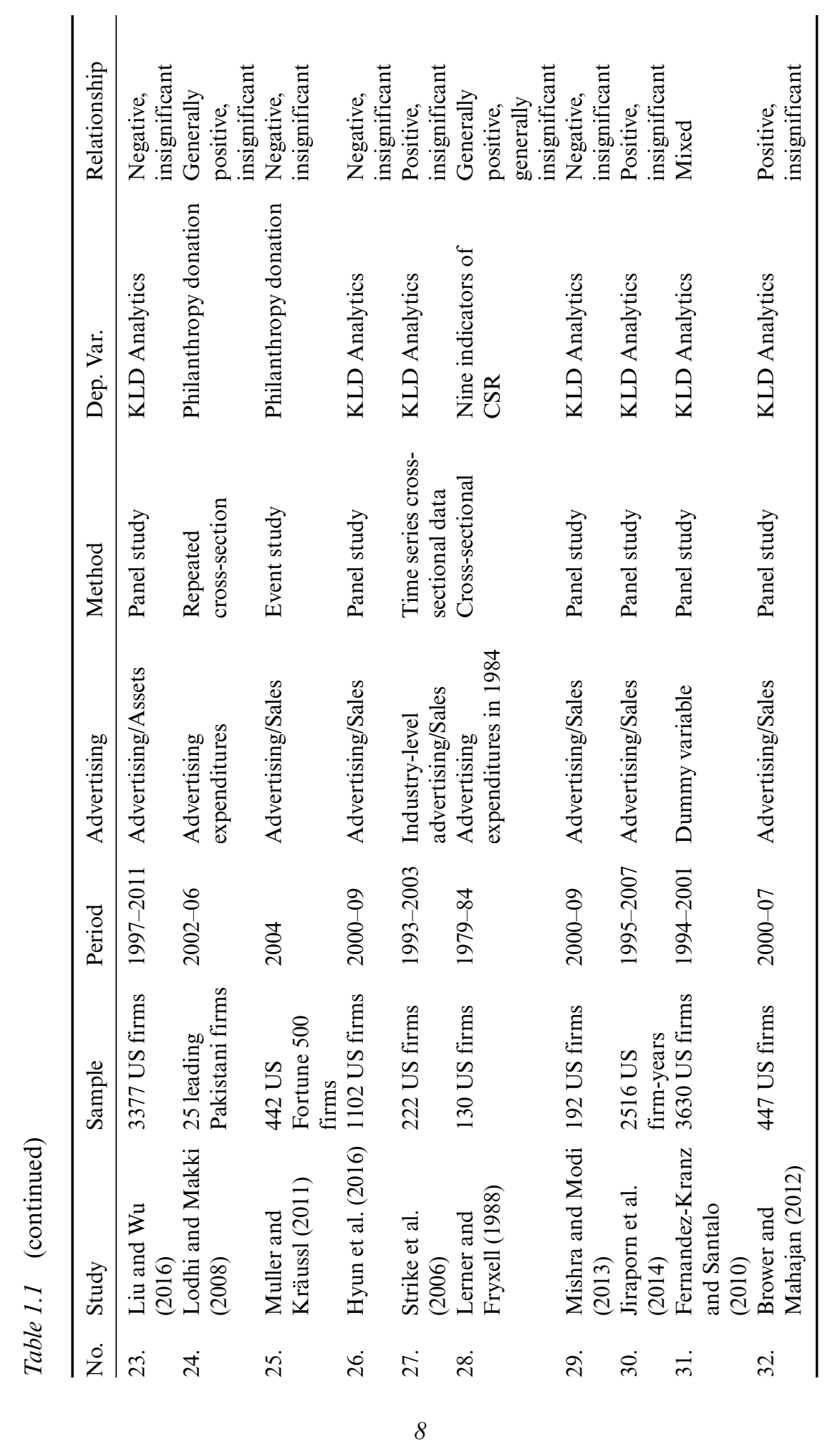


(Harrison and Coombs, 2012). As a whole, this literature casts doubt on the widespread belief that there is a positive, robust, significant relationship from advertising to CSR.

Having read each study in detail, I can attest that the collective difficulty of establishing the relationship from advertising to CSR has not been appreciated by the individual scholars in Table 1.1. Future researchers will need to do more to theorize why this relationship is absent or to discover the boundary, mediating, and moderating conditions that govern the relationship. The sections that follow will assist in this effort by clarifying the prevailing logics that justify an expected relationship from advertising to CSR and by providing yet more evidence that the relationship from advertising to CSR is not very robust.

\section{THEORY AND SCHEMA}

\section{Strategic Logics}

Several logics reinforce the expectation that advertising generates CSR. Figure 1.1 separates these logics into two groups: those related to strategy and those related to politics. There are three logics in the strategic category. Each logic has a critical background condition - strong support for CSR in the general public or among targeted consumers. This background condition is well documented: consistent evidence of positive public

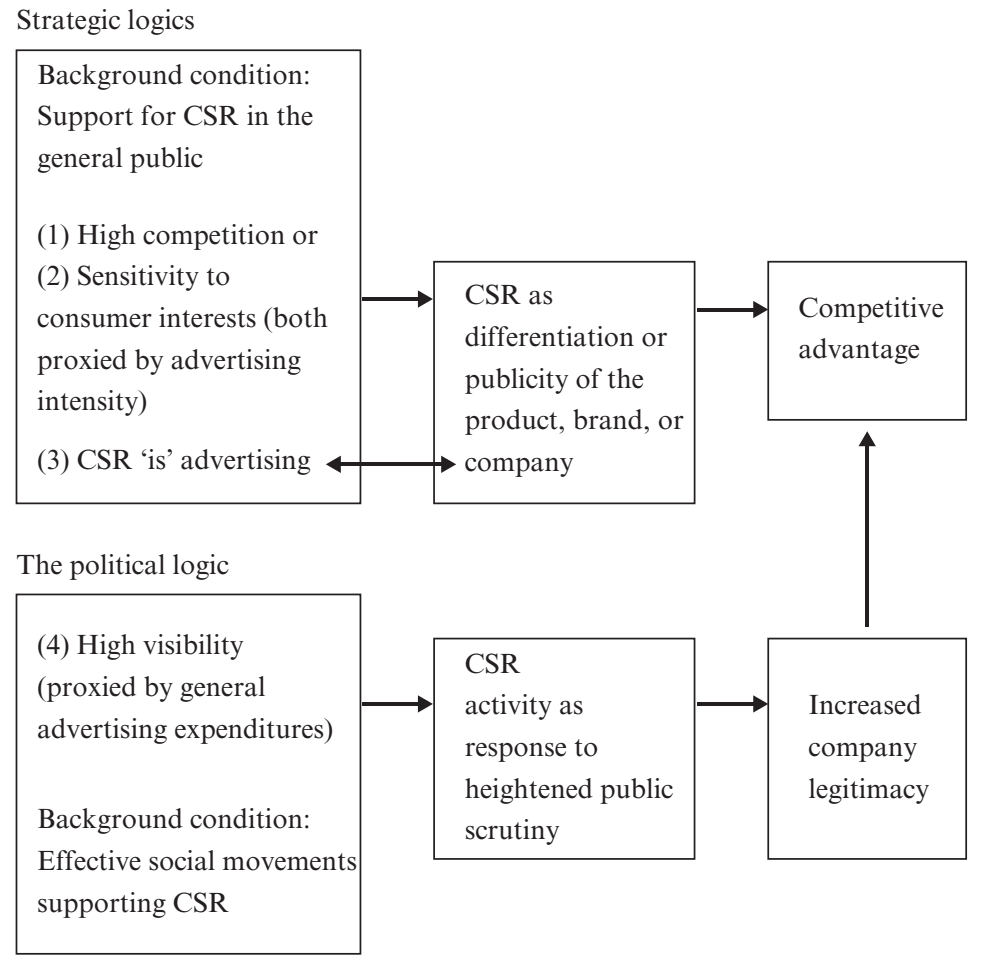

Figure 1.1 Logics supporting a pathway from advertising to CSR 
sentiment toward CSR-practicing companies is found in surveys of not only consumers (Nielsen, 2013), but also investors (World Economic Forum and International Business Leaders Forum, 2003), employees (Turban and Greening, 1997), supply-chain partners (Strangberg Consulting, 2013), and business leaders themselves (Bolívar, Garde Sánchez, and López Hernández, 2014). It is this robust support for CSR across stakeholders that allows CSR, much like advertising, to be used as a form of company differentiation and, some have argued, to be used in a manner that is nearly equivalent to advertising, such that CSR and advertising are substitutable.

The first strategic logic is that high competition generates CSR because CSR enables firms to differentiate themselves from their competitors. 'It might happen,' in other words, 'that firms subject to more competitive environments increase their expenditure in R\&D or advertisement in addition to undertaking CSR initiatives' (Fernandez-Kranz and Santalo, 2010, p.463). This is because CSR, much like R\&D, can be the basis of a differentiation campaign, as CSR is presumably costly (and thus not easily imitable) and as it allows firms to align themselves and their products with emerging consumer CSR preferences (He and Li, 2011; Melo and Garrido-Morgado, 2012).

CSR can provide brand differentiation in numerous ways. It can improve consumer attitudes toward companies (Menon and Kahn, 2003; Wang, 2009). It may mitigate consumer mistrust of companies in the wake of a scandal (Mattila, Hanks, and Kim, 2010). It may raise consumer purchase intent or willingness to pay (Archer, Kozak, and Balsillie, 2005; Hiscox and Smyth, 2006). Overall, studies finding positive economic effects of CSR are diverse, spanning theoretical postulation (McWilliams and Siegel, 2001), survey data (Madden, Roth, and Dillon, 2012), content analysis (Cox, 2008), practitioner interviews (Nicholson, 2007), field experiments (Hiscox and Smyth, 2006), and laboratory experiments (Menon and Kahn, 2003). These studies are diverse also in industrial setting, including the food (Jones, Comfort, and Hillier, 2007), retail (Hiscox and Smyth, 2006), cosmetic (Zhao, 2012), and banking industries (Mattila et al., 2010).

Large advertisers are probably well positioned to gain these differentiation effects from CSR. These companies will be the best able to generate consumer awareness of their CSR deeds, a necessary condition to profit from CSR activity. Indeed, several large-scale regression analyses of American companies have found that CSR communication intermediates between CSR and financial returns (Servaes and Tomayo, 2012; Wagner, 2010). This has led many academics to argue that companies are falling short of their potential by not advertising CSR activities more comprehensively (Birth et al., 2008; Carrigan, 1997).

The second logic construes both advertising and CSR as a proxy for the closeness of companies to consumers. This logic has been stated explicitly in regard to philanthropy, a classic CSR domain. 'Sensitivity to consumer interests,' that is, 'will help to explain a significant, positive relationship between philanthropy and advertising expenditures' (Lerner and Fryxell, 1988, p.952). Reflecting this logic, there have been numerous quantitative studies attempting to predict CSR from the closeness of the companies to their consumers, as measured sometimes by advertising expenditures but also by whether a company is in a consumer-facing industry, such as retail or household items (Galaskiewicz, 1997; Giovannucci, Von Hagen, and Wozniak, 2014).

Extending the first two logics, the third logic draws an equivalence between CSR and advertising. CSR and advertising, here, are each promotional activities intended to enhance corporate reputations. 'Since CSR promotes the reputation of the firm,' in 
other words, 'it may substitute for advertising' and 'social spending is akin to advertising' (Jiraporn et al., 2014, pp. 513 and 505). This logic has also been apparent in scholarship on corporate philanthropy. That is, both philanthropy and advertising may build consumer loyalty: 'As in most cases both corporate philanthropy and advertising serve the common purpose of building customer loyalty, we predict that firms with large advertising expenses will tend to have higher likelihood of giving and to donate larger amounts' (Zhang et al., 2009, p. 40). Indeed, Brammer and Millington (2005, p. 519) suggest that a low marginal cost of philanthropy, compared to the gains in consumer exposure from philanthropy, will generate a shift in resources from advertising to philanthropy. If CSR and advertising are thus equivalent, high advertisers might reasonably be the most likely companies to engage in CSR, either directly or to substitute advertising for CSR.

The hypothesis below, drawing from the three logics above, features the concept of advertising intensity. Advertising intensity is most commonly indicated in empirical research by total advertising expenditures divided by sales, although sometimes assets are the denominator (see Table 1.1). The use of advertising intensity as the key independent variable in empirical research has become conventional, owing in part to its use in one of the earliest studies in this domain (Fry et al., 1982) and to its suggested use by a highly cited agenda-setting piece for CSR research (McWilliams and Siegel, 2001, p. 120). Even so, the quantitative analyses of this chapter, as a check on robustness, test other indicators of advertising, such as total advertising expenditures, both logged and unlogged, and advertising expenditures in which missing values are replaced with a zero.

Our first hypothesis is thus as follows:

\section{Hla: There is a positive relationship from advertising intensity to corporate social responsibility}

While the foregoing suggests that general advertising increases CSR, a slightly different conceptualization may provide a tighter test of the logic of the strategic hypotheses. This conceptualization replaces CSR (in general) with CSR reporting. If CSR is nearly equivalent to advertising, according to the third logic above, then CSR reporting is an even closer equivalent. CSR reporting, as a crude definition, is the standardized dissemination of CSR information to stakeholders often through third-party reporting platforms such as the Carbon Disclosure Project or Global Reporting Initiative (Meyer, Pope, and Isaacson, 2015; Pope and Meyer, 2015; Pope and Lim, 2017). CSR reporting is similar to advertising in that both provide positive informational and persuasive messages about companies to the general public. To justify further an expected relationship between advertising and CSR reporting, since large advertisers have well-practiced corporate identities and longstanding relationships with marketers, they may face lower adoption costs of CSR reporting. At the very least, observers have drawn parallels between CSR reporting and advertising. For example, the CSR reports of global frameworks, for example, the Global Compact and Global Reporting Initiative, are sometimes called 'forms of green marketing in themselves' (Alves, 2009, p. 8) and 'public relations operations' (Capdevila, 2007, p. 1), which allow firms to obtain an undeserved 'branding makeover' (Hildebrandt, 2003, p. 103), 'project a good image' (Utting, 2000, p. 8), and receive a 'free public relations ride' (Thérien and Pouliot, 2006, p. 68). Due to the similarities between advertising and CSR reporting, it is reasonable to expect the following: 


\section{$H 1 b$ : There is a positive relationship from advertising intensity to CSR reporting}

\section{Political Logics}

There is one major political logic. It renders advertising as a proxy for visibility and suggests, further, that visibility leads to CSR through the mechanism of public scrutiny. 'Advertising. . .can also play a role in increasing the visibility of the firm. . . The bigger or more visible, the more susceptible corporations will be to public scrutiny and the more encouraged. . .to engage in strategic CSR' (Melo and Garrido-Morgado, 2012, p. 20). In this logic, visibility, indicated by advertising, prompts CSR in response to present or anticipated pressure from activists.

The power of visibility to promote CSR does not necessarily hinge on advertising as a proxy. Visibility can be operationalized also as company size. Udayasankar (2008), for example, argues that: 'smaller firms may face fewer pressures, or gain little recognition from CSR, given their comparatively lower visibility.' Visibility can also be operationalized as public ownership. Blombäck and Wigren (2009, p. 259), for example, argue that private firms are less visible and thus less likely to undertake CSR. When operationalized as size or public ownership, visibility has been found to have a very consistent relationship with CSR, as evidenced by numerous surveys on ownership structure and CSR (KPMG, 2011, p. 6; Lee, 2009; Li and Zhang, 2010) and by several meta-studies on company size and CSR (Blombäck and Wigren, 2009; Lepoutre and Aimé, 2006; Stanwick and Stanwick, 1998).

The background condition for the political logic, of course, is the presence of social movements that, first, promulgate and enforce CSR norms and, second, do so strategically by targeting highly visible firms. In the first regard, those who take a conflict-theory view of CSR have chronicled many new tactics and platforms by which social movements have compelled companies to improve their CSR performance. For instance, activists have used negative messaging campaigns on Twitter to 'Tweetjack' companies into discontinuing irresponsible practices (Lyon and Montgomery, 2013). They have used similar tactics in the comments sections of news stories and on Facebook pages (Cho and Hong, 2009). They have appropriated and satirized company logos to associate the company with its perceived injustices (Klein, 1999). Their more organized efforts have resulted in the creation of organizational rankings that monitor and ultimately discipline companies according to such metrics as the percentage of women on executive boards and the pounds of carbon emissions (Gjølberg, 2009; Parguel et al., 2011).

In the second regard, quantitative researchers have indeed documented that highly visible firms are targeted more often for social movement activism, even controlling for CSR performance. Bartley (2007b), for example, found that firms with larger assets and higher reputations were targeted with greater intensity by the anti-sweatshop movements of the late 1990s. King (2008) has provided a mechanism to explain this behavior. He has argued and documented that the 'amount of media coverage to any particular boycott is partly a function of the overall salience and visibility of the firm' (p. 405). It is reasonable to expect that social movements, which like other organizations are resource-constrained, may selectively target highly visible firms on the basis that the boycott's power will be magnified by the greater media coverage of highly visible firms. Thus, if there is considerable social movement activism in favor of CSR, if advertising increases a firm's visibility, 
if activists strategically target visible firms, and especially if media organizations amplify these campaigns, the following is likely:

H2: There is a positive relationship from advertising to corporate social responsibility

\section{METHODS}

\section{Sample}

The sample of the chapter is the 2010 Fortune Global 500, compiled by Fortune magazine, an American bi-weekly for popular and business audiences with a circulation of about 800000 . Global 500 companies are the largest in the world by annual revenues. A common academic sample (e.g., Carroll and Sapinski, 2010), the Global 500 includes public, private, and state-owned companies (about 75 percent are public), with representation from all ten sectors of the Global Industrial Classification Scheme (GICS) and from 35 countries. Global 500 companies, it should be noted, are not necessarily international. Many are state-owned, nationally oriented companies such as China National Petroleum and Japan Post Holdings (both ranked in the top 50). Thus, to increase international representation in the current sample, Global 500 companies are supplemented with the lists of 100 Largest Transnationals from 1999 to 2010 (including the sublists 'The World's Most Transnational Banks' and 'The World's Most Transnational Companies from Developing Nations'). Produced by the United Nations Conference on Trade and Development and published annually in the World Investment Report, these lists rank companies by the average of their percentage of employees, sales, and foreign assets. The final combined sample has 705 companies.

\section{Dependent Variables}

For H1a and H2, CSR is indicated by the CSR ratings of the Thomson-Reuters ASSET4 database. This database, retrieved through Datastream and active since 2002, assigns 4300 of the largest global companies (members of leading stock indices around the world such as the S\&P 500 and the MSCI Emerging Markets) a score on their environmental, social, and governance performance (the score ranges from 0 to 100 to reflect the percentile rank of companies), based on a complex proprietary methodology that includes 18 data categories, which are based on 250 key performance indicators, which are themselves based on 750 data points. Since corporate governance is not commonly perceived to be a core dimension of CSR, it is excluded from the present analyses.

For $\mathrm{H} 1 \mathrm{~b}, \mathrm{CSR}$ reporting is indicated by three binary variables for yearly participation in three leading global CSR reporting initiatives. These are the Global Compact (GC), Global Reporting Initiative (GRI), and Carbon Disclosure Project (CDP). Figure 1.2 reports summary statistics and key details about each initiative. The initiatives were selected from globally oriented CSR guidebooks and compendiums (e.g., Visser et al., 2010) as those satisfying these requirements: longstanding (greater than ten-year history), independent (not administered by firms themselves), global (participation in scores of nations), pan-industry, and mostly firm-level membership (not factories, subsidiaries, or 

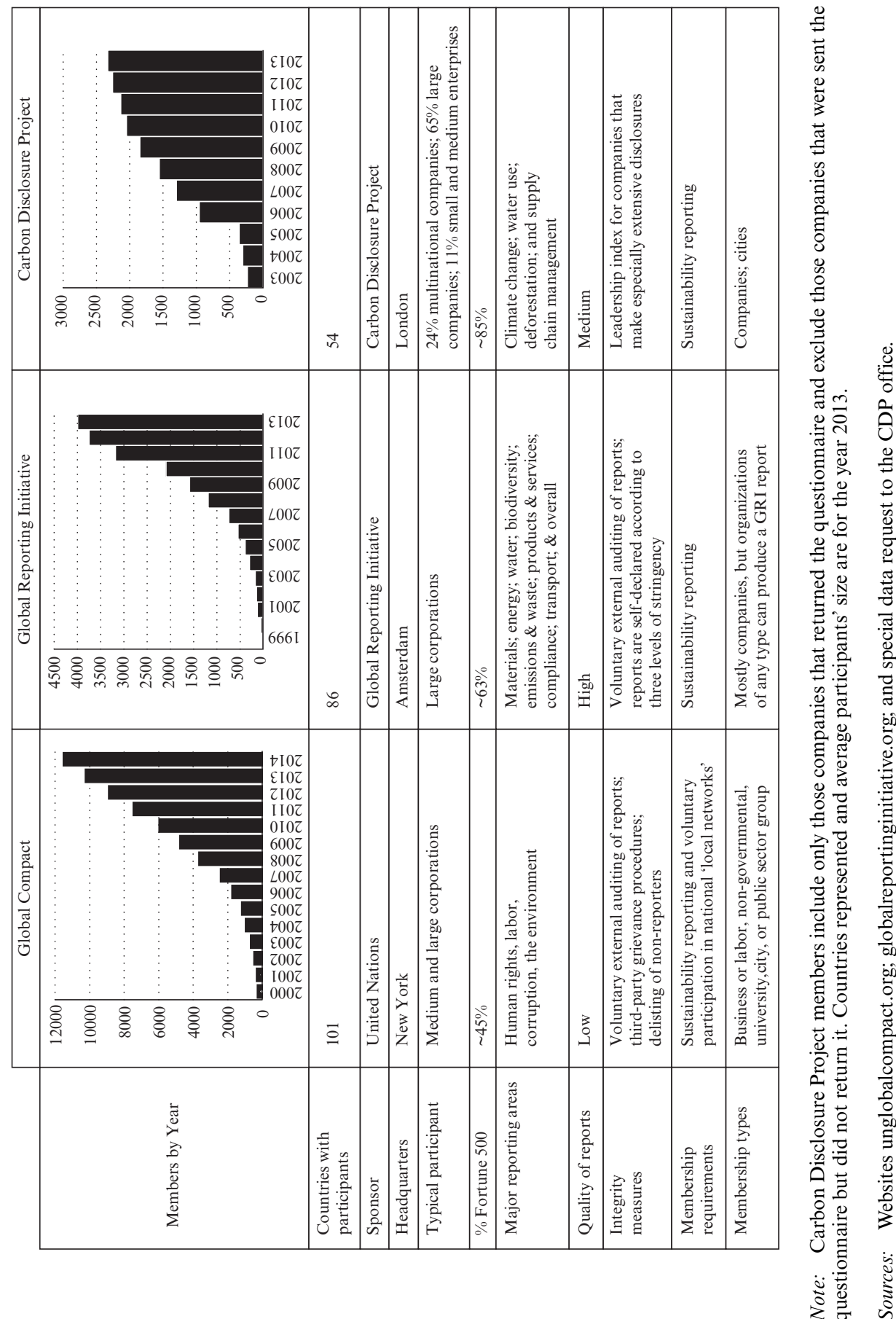

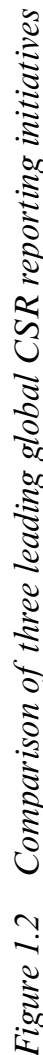


nation-states). Each initiative requires the production of a voluntary annual report with standardized CSR disclosures at the corporate level. Each initiative has dramatically increased its membership roster since the turn of the millennium, with the GC now having more than 8000 members, the GRI 4000, and the CDP 2000. Figure 1.2 shows that the substance of the reports that are required for membership in each initiative is wide ranging, with coverage that spans the topics of human rights, supply chain management, and biodiversity. GC is coded as 1 for members in good standing. GRI is 1 in the years a firm submits a GRI report to the GRI offices. CDP is 1 in the years a company responds to the main CDP survey (companies not sent the survey are dropped from analysis).

\section{Independent Variables}

The first and most standard indicator of advertising (see the previous studies in Table 1.1) is annual advertising expenditures divided by annual sales, an indicator known as advertising intensity. Because sales, but not advertising, can be negative, negative sales and thus negative advertising intensities are dropped from the analysis. A few cases are also dropped where revenues are less than advertising, constraining advertising intensity to a fraction between 0 and 1 . Given that advertising intensity, according to previous research, does not have a track record of a positive, significant relationship with CSR, I have also included other codings of advertising. More specifically, I include in the models total advertising expenditures (logged and unlogged) and an indicator of advertising intensity in which missing values are replaced with zeros (following Servaes and Tamayo, 2012). I note that replacing missing advertising expenditures with zeros, in my opinion, may introduce a lot of empirical slippage, given that there are notable companies that are reported to have missing advertising expenditures but that clearly have them in all years (e.g., Walt Disney).

Excessive missing data is common for advertising expenditures that are retrieved from major financial databases. American-listed firms, for example, are not required to report expenditures to the Securities and Exchange Commission - and most do not. Compustat lacks advertising for as much as 74 percent of company-years in recent studies (Baron, Harjoto, and Jo, 2009, p. 22). Excessive missing data has prompted coping mechanisms. Researchers have dropped the variable (Tashman and Rivera, 2010); assigned nonreporters a value of zero (Servaes and Tamayo, 2012); assigned industry averages (Hull and Rothenberg, 2008); and created dummies for whether advertising is reported (Baron et al., 2009) or for appearance in trade-journal lists of top advertisers (Bartley and Child, 2012). A better approach that does not sacrifice granularity is to chase down missing values by merging multiple financial databases, as individual databases are not always thorough in their data capture. This study gathers company-level, USD, annual, worldwide expenditures not only from Compustat (following previous studies), but also from Thomson-Reuters, Capital IQ, and the Top 100 Global Marketers lists from 2000-14 of Advertising Age. ${ }^{1}$ Compiling across databases yields more company-years than does any single database - 2445 - versus the 1171 of Compustat, 2009 of Thomson-Reuters, 1163 of Capital IQ, and 1055 of Advertising Age. In the few cases with discrepancies across the databases, priority went to Thomson, then Compustat, then Capital IQ, and then Advertising Age. 


\section{Control Variables}

Potential confounds include dummies for year, headquarters region (Europe, Asia and the Pacific, Africa and the Middle East, Latin America and the Caribbean, and Canada and the United States) and the ten sectors of the GICS. These controls are broad (regions versus countries, sectors versus industries) to avoid overspecification and, relatedly, to reduce Type II errors (given the prominence of the view that advertising increases CSR, a false positive that supports this hypothesis seems preferable to a false negative that contradicts it). Size is another control - annual, USD, total assets rather than revenues, which are present already in the denominator of advertising intensity. Assets are logged due to a right skew that causes a rejection of the null hypothesis that skewness and kurtosis approximate a Gaussian distribution $(p<0.01$; sktest in Stata).

\section{Models}

For H1a and H2, to predict ASSET4 scores, which are positive and nearly continuous variables, OLS panel regressions are specified in Stata 11. Residuals are company clustered and Huber-White robust standard errors are used as a basic guard against inconsistent heteroscedasticity. For $\mathrm{H} 1 \mathrm{~b}$, the models predicting membership in the leading CSR reporting platforms are logistic regressions, since this membership is best coded as a binary variable.

\section{RESULTS}

Univariate statistics appear in Table 1.2. The measures of advertising are moderately $(0.02$ to 0.28$)$ and generally significantly $(p<0.05)$ associated with the measures of CSR. In terms of the hypotheses, the strongest correlations are between logged total advertising expenditures and all measures of CSR.

Table 1.3, which tests H1a and H2 (that advertising increases CSR) does not yield very robust evidence in favor of the hypotheses. As with previous literature in this research area, the relationship between the two constructs is generally positive and generally insignificant. As with the univariate statistics, however, the relationship appears to be stronger when logged total advertising expenditures are used as the advertising indicator, resulting in coefficients that are significant and positive for both the social and environmental scores of ASSET4. Even so, these findings as a whole do not robustly support a relationship from advertising to CSR.

$\mathrm{H} 1 \mathrm{~b}$ predicts that advertising increases CSR reporting. As additional descriptive evidence, Figure 1.3 is a bar chart showing the number of companies in the global CSR reporting initiatives by industry (using the industry coding format as reported in each database). At a glance, the bar charts give little indication that the industries that are consumer facing, or that are otherwise heavy advertisers, have outsized initiative participation. For the Global Compact, the most represented industry by far, having a margin of over 2000 companies over the next most represented industry, is 'Industrial Goods and Services.' Companies in this industry tend to be intermediate manufacturers that are not oriented toward consumers, but to other companies. Moreover, when 


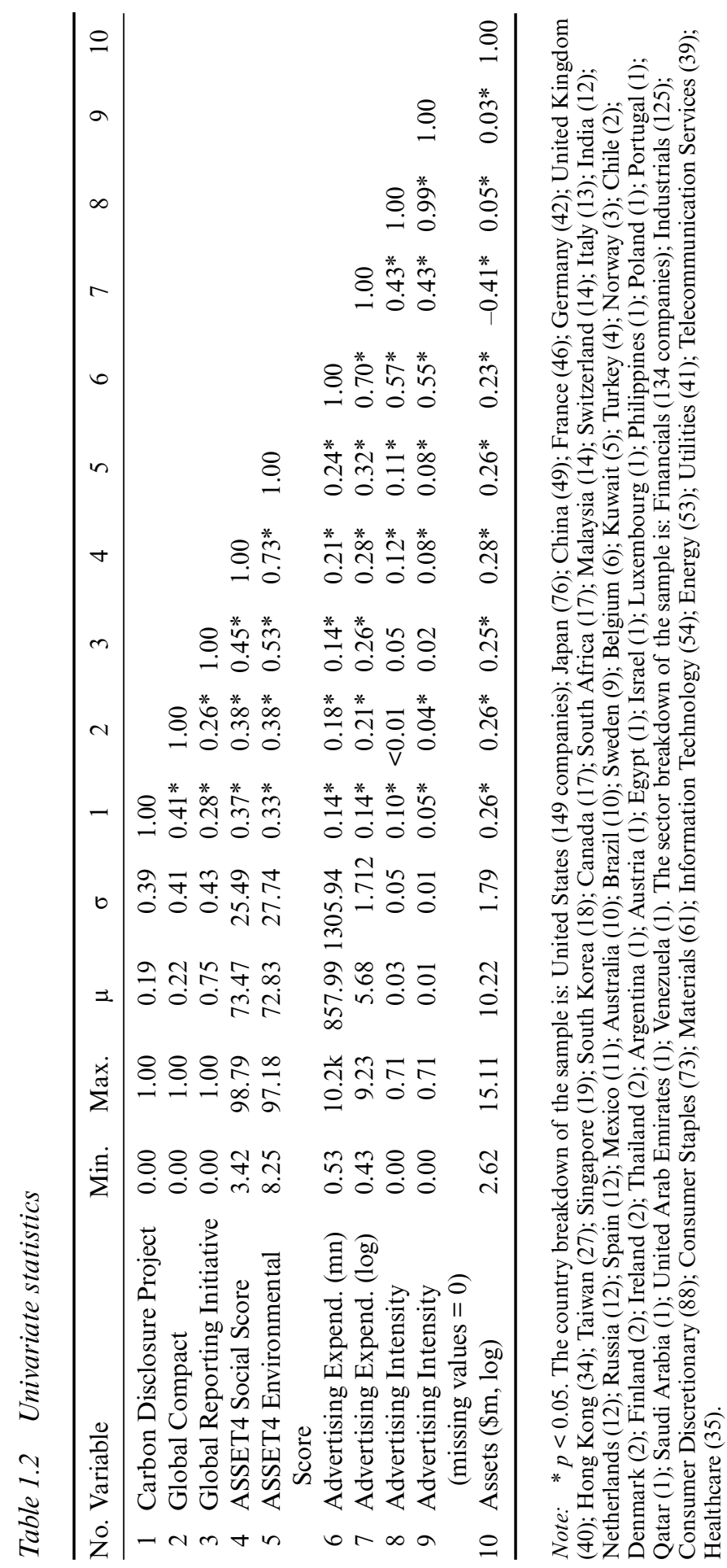




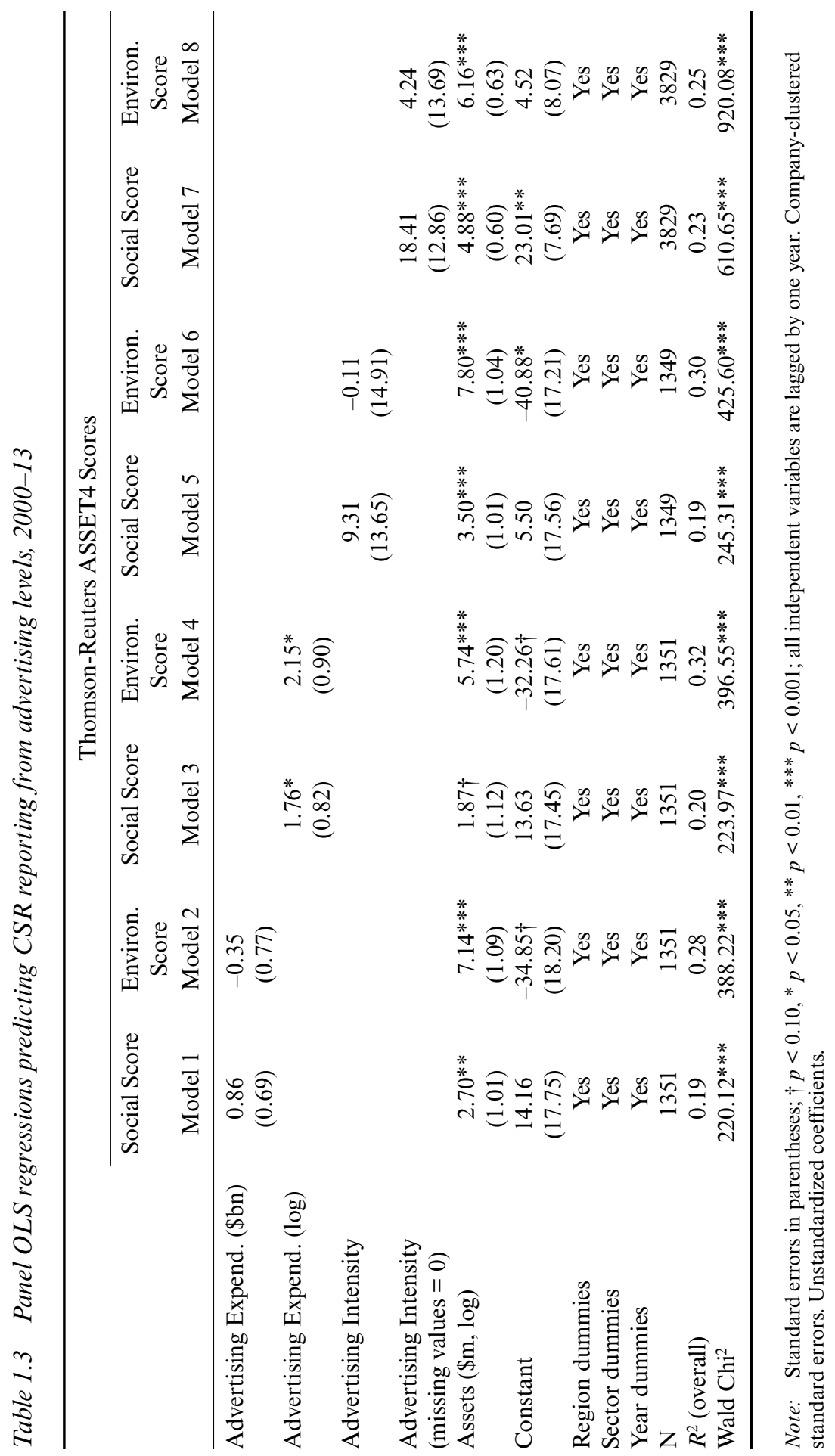



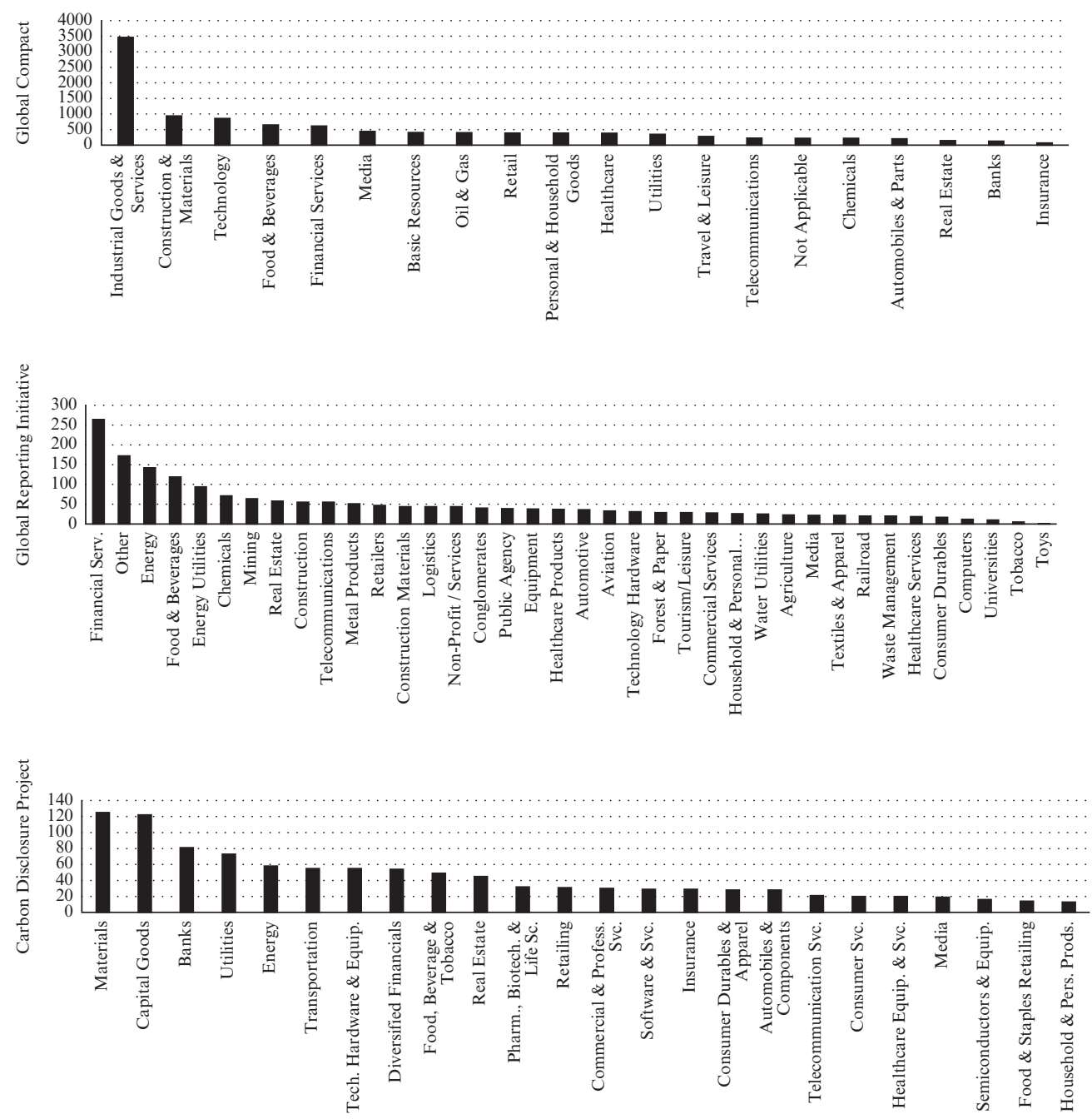

Note: CDP data are for the year 2011; industry codes were not provided for later years.

Figure 1.3 Number of participants in global CSR reporting initiatives by industry

broken down by subindustries (an analysis that is not shown for reasons of space), the largest subindustry in the Global Compact is Support Services. There are 1651 members in this subindustry, many more members than those in the next largest subindustry ('Construction \& Materials,' 940 members). Companies in the Support Services industry include accountants, consultants, and placement agencies, which receive almost all their revenues from other companies rather than consumers. By contrast, industries that one might expect to have high advertising intensities are not well represented in the initiatives. For example, retail companies are ranked 9th in the Global Compact, 12th in the Global Reporting Initiative, and 12th in the Global Compact. Similarly, 
'Personal \& Household Goods' rank 10th in the Global Compact and last in the Carbon Disclosure Project.

As additional descriptive evidence, Figure 1.4 presents another way to visualize the relationship between industry-level advertising intensity and industry-level participation in the global CSR initiatives. Each bubble in Figure 1.4 represents a two-digit industry of the Standard Industrial Classification scheme that is represented in the current sample. The bubbles are plotted along two axes. The $\mathrm{x}$-axis represents the average number of years that companies in each industry are members of the respective CSR initiatives. The $y$-axis represents the average advertising intensity by industry of companies in the current sample. The dotted line is a trend line fitted by the method of ordinary least squares. For each initiative, the industry-level relationship between advertising intensity and initiative participation is negative. That is, industries with higher advertising intensity tend to have lower rates of initiative participation. This relationship contradicts the assumption that there is a strong positive relationship between advertising intensity and initiative participation.

The regressions in Table 1.4 are also not very supportive of the hypothesis that advertising increases CSR reporting. Here, as with the above, the coefficients of advertising are generally positive and generally insignificant. The sole exception is when advertising is treated as logged total advertising, generating a coefficient that is significant and positive for GRI membership. It must be noted, however, that this same variable is negative and marginally significant $(p<0.10)$ when predicting GC membership, and thus that the relationship is not robust across initiatives.

\section{DISCUSSION}

Scholarly investigations into whether advertising generates CSR are well underway, but the results of these inquiries have not been very supportive. On average, only about a third of studies have been able to document a positive relationship from advertising to CSR. The present study, likewise, has not improved the evidence in favor of the expected relationship. The present findings have been weak and mixed, despite models that were specified parsimoniously and despite extensive efforts to increase statistical power by chasing down missing values for advertising expenditures from multiple databases.

It should be mentioned that the present findings, which failed to observe a relationship from advertising to CSR, may appear more credible alongside a growing body of research that has failed to document the other direction of causality. This body of research shows that CSR, in general, fails to result in increased advertising to promote awareness of the good deeds. It is true that this body of research has been limited by the inability to gather expenditures on CSR advertising specifically, in contrast with total advertising generally, precluding researchers from conducting long- $\mathrm{T}$, large- $\mathrm{N}$ quantitative studies. However, the literature has included many cross-sectional and qualitative studies, such as surveys, interviews, and case studies (e.g., Nicholson, 2007; Pomering and Dolnicar, 2009; Russo and Tencati, 2008; Tixier, 2003). The results of these studies have been remarkably consistent: many, perhaps most CSR-practicing companies, do not advertise their good deeds. Moreover, the ones that do advertise their good deeds tend to engage only in local, limited, internal, or ad hoc advertising. 


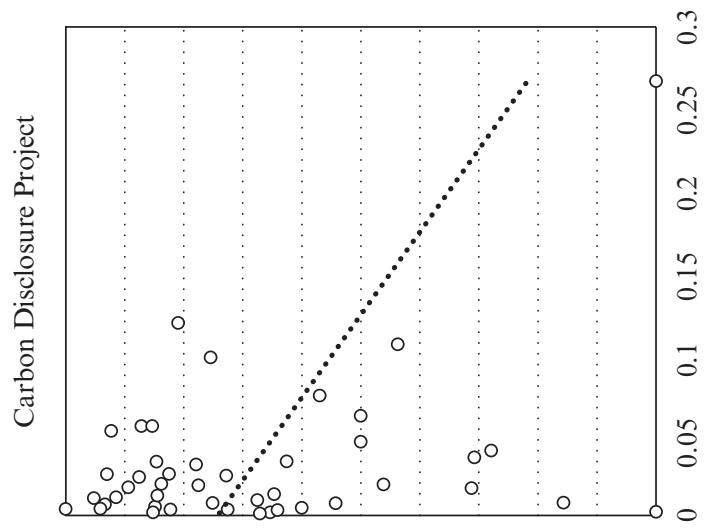

3
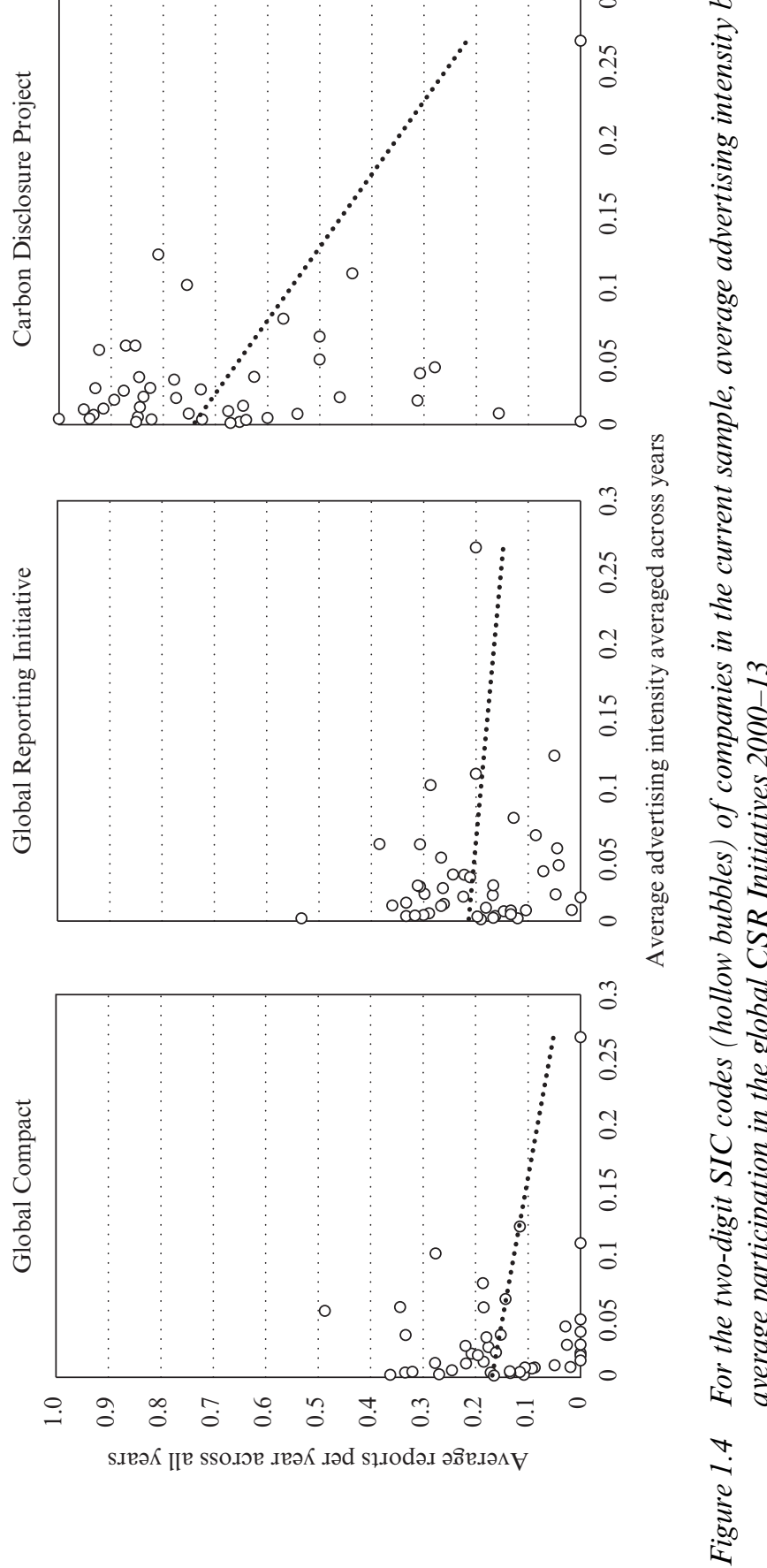


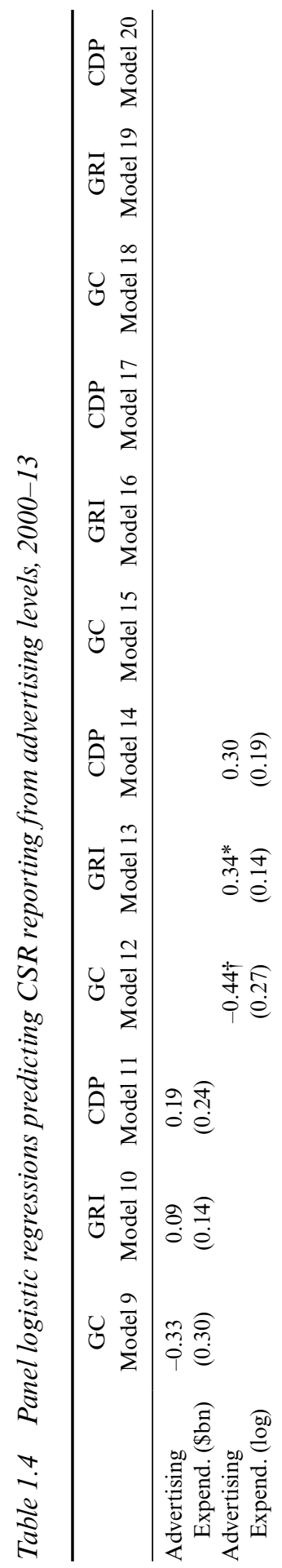

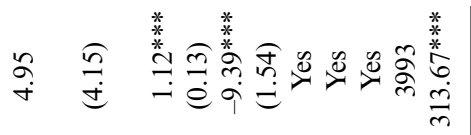

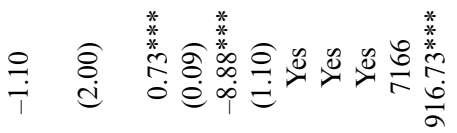

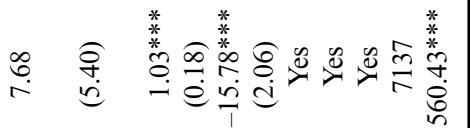

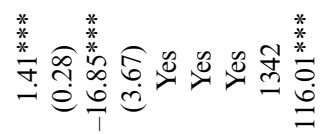$$
\text { ชே. }
$$

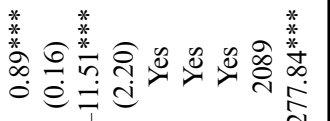

ic $0 \dot{e}=a^{-}$

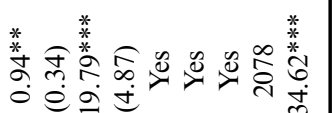

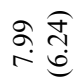
○ें

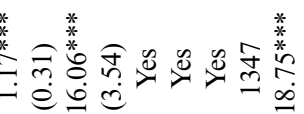

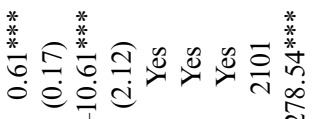

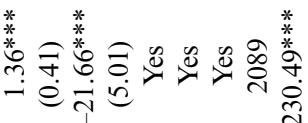

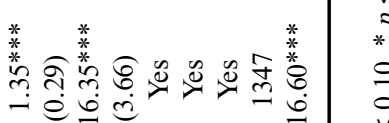

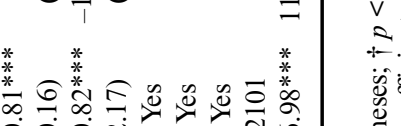

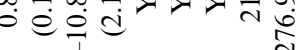

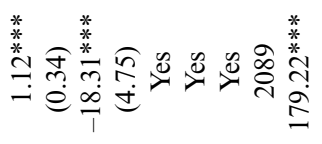

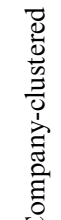
苛 它 
This finding of an absent relationship from CSR to advertising is particularly puzzling given the obvious growth in CSR advertising in recent decades. This growth has been documented quantitatively by longitudinal content analyses (Ahern, Bortree, and Smith, 2013; Leonidou et al., 2011; Lill, Gross, and Peterson, 1986; Mögele and Tropp, 2010). Reflecting this growth, advertisements with a CSR theme are now common on television and in print (Mögele and Tropp, 2010). New CSR advertising techniques have been deployed, such as corporate-non-profit alliances and cause-related marketing (Varadarajan and Menon, 1988). Company websites feature the advertisements, often as links to glossy electronic CSR reports or to mission statements that feature CSR language (Hooghiemstra, 2000). Product labels are another medium, and packaging is now common that advertises 'fair trade' and 'sustainability,' for example, in the coffee (Basu and Hicks, 2008), apparel (Hustvedt and Bernard, 2008), timber (Archer et al., 2005), seafood (Gudmundsson and Wessells, 2000), orange juice (Grankvist and Lekedal, 2007), and meat industries (Binnekamp and Ingenbleek, 2008).

Notwithstanding this apparent growth in CSR advertising, it is becoming clearer with each new quantitative study that there is not a very strong link between advertising and CSR or between CSR and advertising, despite the prominence of several lines of strategic CSR theory that would expect such an outcome. Future researchers will need to do much more to determine why a presumed relationship between advertising and CSR is absent. My own suspicion is that researchers will succeed if they devote more consideration to the alternative explanation that CSR tends to be adopted for reasons that are not narrowly strategic.

Along these lines, in my own meta-study of 200 surveys conducted since the late 1990 s that ask managers why they engage in CSR (Pope, 2016), the most common explanation in all world regions and across all years is that CSR is adopted for ethical, moral, and normative reasons, rather than for strategic or political reasons (the very reasons that suggest a relationship from advertising to CSR). Clearly CSR that is adopted, for example, due to ethical motivations, does not necessitate high advertising expenditures before or after adoption. The adoption itself satisfies the initial motivation. However, this conception of CSR adoption very much runs against the strategic and political accounts that dominate the CSR literature. While some companies may engage in political and strategic CSR, most companies probably adopt CSR for normative reasons, especially as CSR has become a popular, international, and perhaps taken-for-granted movement in recent decades.

\section{NOTE}

1. Advertising Age is a trade journal with 40000 subscribers and perhaps the industry leading source for marketing and media news' (MeritDirect, 2013). Lists are available by subscription (\$80/year) to the 'AdAge Datacenter' and compiled from surveys of advertising agencies and media monitoring firms in more than 95 countries. 2014 lists included mostly public companies ( 80 percent), spanned eight of ten Global Industry Classification Standard (GICS) sectors, skewed toward Consumer Staples (32 percent) and Consumer Discretionary (31 percent), and contained 14 headquarter nations, with the USA as the mode (48 percent). Utilizing these lists ensures that the dataset has complete expenditures for the largest advertisers. 


\section{REFERENCES}

Aguilera, R.V., Rupp, D.E., Williams, C.D., and Ganapathi, J. (2007). Putting the S back in Corporate Social Responsibility: A multilevel theory of social change in organizations. Academy of Management Review, 32(3), 836-63.

Ahern, L., Bortree, D.S., and Smith, A.N. (2013). Key trends in environmental advertising across 30 years in National Geographic magazine. Public Understanding of Science, 22(4), 479-94.

Alves, I.M. (2009). Green spin everywhere: How greenwashing reveals the limits of the CSR paradigm. Governance: An International Journal of Policy and Administration, II(1), 1-26.

Amato, L.H., and Amato, C.H. (2007). The effects of firm size and industry on corporate giving. Journal of Business Ethics, 72(3), 229-41.

Amato, L.H., and Amato, C.H. (2012). Retail philanthropy: Firm size, industry, and business cycle. Journal of Business Ethics, 107(4), 435-48.

Archer, H., Kozak, R., and Balsillie, D. (2005). The impact of forest certification labelling and advertising: An exploratory assessment of consumer purchase intent in Canada. The Forestry Chronicle, 81(2), 229-44.

Baron, D.P., Harjoto, M.A., and Jo, H. (2009). The economics and politics of corporate social performance. Stanford Working Paper No. 1993R.

Bartley, T. (2007a). Institutional emergence in an era of globalization: The rise of transnational private regulation of labor and environmental conditions. American Journal of Sociology, 113(2), 297-351.

Bartley, T. (2007b). Standards for sweatshops: The power and limits of club theory for explaining voluntary labor standards programs. In M. Potoski and A. Prakash (eds), Voluntary Programs: A Club Theory Approach, pp. 107-32. Cambridge, MA: MIT Press.

Bartley, T., and Child, C. (2012). Movements, markets, and fields: The effects of anti-sweatshop campaigns on U.S. firms, 1993-2000. Social Forces, 90(2), 425-51.

Basu, A.K., and Hicks, R.L. (2008). Label performance and the willingness to pay for fair trade coffee: A cross-national perspective. International Journal of Consumer Studies, 32(5), 470-78.

Binnekamp, M., and Ingenbleek, P. (2008). Do 'good' food products make others look 'bad'? Spin-off effects of labels for sustainable food production in the consumer perception. British Food Journal, 110(9), 843-64.

Birth, G., Illia, L., Lurati, F., and Zamparini, A. (2008). Communicating CSR: Practices among Switzerland's top 300 companies. Corporate Communications: An International Journal, 13(2), 182-96.

Blombäck, A., and Wigren, C. (2009). Challenging the importance of size as determinant for CSR activities. Management of Environmental Quality: An International Journal, 20(3), 255-70.

Bolívar, M.P.R., Garde Sánchez, R., and López Hernández, A.M. (2014). Managers as drivers of CSR in stateowned enterprises. Journal of Environmental Planning and Management, 568, 1-25.

Brammer, S., and Millington, A. (2005). Corporate reputation and philanthropy: An empirical analysis. Journal of Business Ethics, 61(1), 29-44.

Brammer, S., Pavelin, S., and Porter, L.A. (2009). Corporate charitable giving, multinational companies and countries of concern. Journal of Management Studies, 46(4), 575-96.

Brower, J., and Mahajan, V. (2013). Driven to be good: A stakeholder theory perspective on the drivers of corporate social performance. Journal of Business Ethics, 117(2), 313-31.

Capdevila, G. (2007). Global compact with business 'lacks teeth' - NGOs. Global Policy Forum, July 6, 2007. Accessed November 11, 2017 at https://www.globalpolicy.org/global-taxes/32268-global-compact-withbusiness-lacks-teeth-ngos.html.

Carrigan, M. (1997). The great corporate give-away - can marketing do good for the 'do-gooders'? European Business Journal, 9(4), 40-46.

Carroll, W.K., and Sapinski, J.P. (2010). The global corporate elite and the transnational policy-planning network, 1996-2006: A structural analysis. International Sociology, 25(4), 501-38.

Casey, R.J., and Grenier, J.H. (2015). Understanding and contributing to the enigma of corporate social responsibility (CSR) assurance in the United States. Auditing, 34(1), 97-130.

Chen, M.H., and Lin, C.P. (2015). Understanding corporate philanthropy in the hospitality industry. International Journal of Hospitality Management, 48, 150-60.

Chintrakarn, P., Jiraporn, P., Kim, J.-C., and Kim, Y.S. (2016). The effect of corporate governance on corporate social responsibility. Asia-Pacific Journal of Financial Studies, 45(1), 102-23.

Cho, S., and Hong, Y. (2009). Netizens' evaluations of corporate social responsibility: Content analysis of CSR news stories and online readers' comments. Public Relations Review, 35(2), 147-9.

Cox, M.J. (2008). Sustainable communication: A study of green advertising and audience reception within the growing arena of corporate social responsibility. Case study: British Petroleum. Earth and Environment, 3, $32-51$.

Crisp, R. (1987). Persuasive advertising, autonomy, and the creation of desire. Journal of Business Ethics, 6(5), 413-18. 
Dahlmann, F., Brammer, S., and Millington, A. (2008). Environmental management in the United Kingdom: New survey evidence. Management Decision, 46(2), 264-83.

Delmas, M.A., and Montiel, I. (2008). The diffusion of voluntary international management standards: Responsible care, ISO 9000 and ISO 14001 in the chemical industry. Policy Studies Journal, 36(1), 65-93.

De Pelsmacker, P., Driesen, L., and Rayp, G. (2005). Do consumers care about ethics? Willingness to pay for fair-trade coffee. Journal of Consumer Affairs, 39(2), 363-85.

De Quevedo-Puente, E., De La Fuente-Sabaté, J.M., and Delgado-García, J.B. (2007). Corporate social performance and corporate reputation: Two interwoven perspectives. Corporate Reputation Review, 10(1), 60-72.

Eckhardt, G.M., Belk, R., and Devinney, T.M. (2010). Why don't consumers consume ethically? Journal of Consumer Behaviour, 9(6), 426-36.

Fernandez-Kranz, D., and Santalo, J. (2010). When necessity becomes a virtue: The effect of product market competition on corporate social responsibility. Journal of Economics and Management Strategy, 19(2), $453-87$.

Fry, L.W., Keim, G.D., and Meiners, R.E. (1982). Corporate contributions: Altruistic or for-profit. Academy of Management Journal, 25(1), 94-106.

Galaskiewicz, J. (1997). An urban grants economy revisited: Corporate charitable contributions in the twin cities, 1979-81, 1987-89. Administrative Science Quarterly, 41, 445-71.

Gao, Y., and Hafsi, T. (2015). Government intervention, peers' giving and corporate philanthropy: Evidence from Chinese private SMEs. Journal of Business Ethics, 132(2), 433-47.

Giovannucci, D., Von Hagen, O., and Wozniak, J. (2014). Corporate social responsibility and the role of voluntary sustainability standards. In C. Schmidz-Hoffmann, C. Schmidt, M.B. Hansmann, and D. Palekhov (eds), Voluntary Standard Systems - A Contribution to Sustainable Development, pp. 359-84. Berlin: Springer.

Gjølberg, M. (2009). Measuring the immeasurable? Constructing an index of CSR practices and CSR performance in 20 countries. Scandinavian Journal of Management, 25(1), 10-22.

Grankvist, G., and Lekedal, H. (2007). Values and eco- and fair-trade labelled products. British Food Journal, 109(2), 169-81.

Gudmundsson, E., and Wessells, C.R. (2000). Ecolabeling seafood for sustainable production: Implications for fisheries management. Marine Resource Economics, 15(96), 97-113.

Hapitan, R.B. (2013). An analysis of the signaling model of corporate philanthropy for selected Philippine banks. Journal of International Business Research, 11(2), 45-57.

Harjoto, M., and Jo, H. (2011). Corporate governance and CSR nexus. Journal of Business Ethics, 100(1), $45-67$.

Harjoto, M., Laksmana, I., and Lee, R. (2015). Board diversity and corporate social responsibility. Journal of Business Ethics, 132(4), 641-60.

Harrison, J.S., and Coombs, J.E. (2012). The moderating effects from corporate governance characteristics on the relationship between available slack and community-based firm performance. Journal of Business Ethics, 107(4), 409-22.

He, H., and Li, Y. (2011). CSR and service brand: The mediating effect of brand identification and moderating effect of service quality. Journal of Business Ethics, 100(4), 673-88.

Hildebrandt, P.M. (2003). Globalisation and governance: The UN Global Compact - reflections on the changing nature of international authority. NORD-Sud Aktuell, 1.

Hiscox, M.J., and Smyth, N.F.B. (2006). Is there consumer demand for improved labor standards? Evidence from field experiments in social labeling. Working Paper, Department of Government, Harvard University.

Hooghiemstra, R. (2000). Corporate and impression management: New perspectives why companies engage in corporate social reporting. Journal of Business Ethics, 27(1/2), 55-68.

Hull, I., and Rothenberg, S. (2008). Firm performance: The interactions of corporate social performance with innovation and industry differentiation. Strategic Management Journal, 29(7), 781-9.

Hustvedt, G., and Bernard, J.C. (2008). Consumer willingness to pay for sustainable apparel: The influence of labelling for fibre origin and production methods. International Journal of Consumer Studies, 32(5), 491-98.

Hyun, E., Yang, D., Jung, H., and Hong, K. (2016). Women on boards and corporate social responsibility. Sustainability, 8(4), 300 .

Jiraporn, P., Jiraporn, N., Boeprasert, A., and Chang, K. (2014). Does corporate social responsibility improve credit ratings? Evidence from geographic identification. Financial Management, 43(3), 505-31.

Jones, P., Comfort, D., and Hillier, D. (2007). What's in store? Retail marketing and corporate social responsibility. Marketing Intelligence \& Planning, 25(1), 17-30.

Kabongo, J.D., Chang, K., and Li, Y. (2013). The impact of operational diversity on corporate philanthropy: An empirical study of U.S. companies. Journal of Business Ethics, 116(1), 49-65.

Katz, J.H. (2010). Contention and corporate social responsibility. Industrial and Labor Relations Review, 63(3), $545-8$.

King, B.G. (2008). A political mediation model of corporate movement activism. Administrative Science Quarterly, 53, 395-421.

King, B.G., and Soule, S.A. (2007). Social movements as extra-institutional entrepreneurs: The effect of protests on stock price. Administrative Science Quarterly, 52(3), 413-42. 
Klein, N. (1999). No Logo: Taking on the Brand Bullies. Toronto: Random House Canada.

KPMG. (2011). International Survey of Corporate Responsibility Reporting 2011. Accessed November 11, 2017 at www.econsense.de/sites/all/files/Survey-corporate-responsibility-reporting-2011.pdf.

Lee, M.P. (2009). Does ownership form matter for corporate social responsibility? A longitudinal comparison of environmental performance between public, private, and joint-venture firms. Business and Society Review, 114(4), 435-57.

Leonidou, L.C., Leonidou, C., Palihawadana, D., and Hultman, M. (2011). Evaluating the green advertising practices of international firms: A trend analysis. International Marketing Review, 28(1), 6-33.

Lepoutre, J., and Aimé, H. (2006). Investigating the impact of firm size on small business social responsibility: A critical review. Journal of Business Ethics, 67(3), 257-73.

Lerner, L.D., and Fryxell, G.E. (1988). An empirical study of the predictors of corporate social performance: A multi-dimensional analysis. Journal of Business Ethics, 7(12), 951-9.

Li, W., and Zhang, R. (2010). Corporate social responsibility, ownership structure, and political interference: Evidence from China. Journal of Business Ethics, 96(4), 631-45.

Ligos, G., and Guritz, R. (1994). Corporate sponsorship income. IRS: 1994 EO CPE Text. Accessed November 11, 2017 at https://www.irs.gov/pub/irs-tege/eotopico94.pdf.

Lill, D., Gross, C., and Peterson, R. (1986). The inclusion of social-responsibility themes by magazine advertisers: A longitudinal study. Journal of Advertising, 15(2), 35-41.

Liu, S., and $\mathrm{Wu}, \mathrm{D}$. (2016). Competing by conducting good deeds: The peer effect of corporate social responsibility. Finance Research Letters, 16(14), 47-54.

Lodhi, S., and Makki, M. (2008). Determinants of corporate philanthropy in Pakistan. Pakistan Journal of Commerce and Social Sciences, 1, 17-24.

Lyon, T.P., and Montgomery, A.W. (2013). Tweetjacked: The impact of social media on corporate greenwash. Journal of Business Ethics, 118(4), 747-57.

Lys, T., Naughton, J.P., and Wang, C. (2015). Signaling through corporate accountability reporting. Journal of Accounting and Economics, 60(1), 56-72.

Madden, T., Roth, M.S., and Dillon, W.R. (2012). Global product quality and corporate social responsibility perceptions: A cross-national study of halo effects. Journal of International Marketing, 20(1), $42-57$.

Madsen, P.M., and Rodgers, Z.J. (2015). Looking good by doing good: The antecedents and consequences of stakeholder attention to corporate disaster relief. Strategic Management Journal, 36(5), $776-94$.

Masulis, R.W., and Reza, S.W. (2015). Agency problems of corporate philanthropy. Review of Financial Studies, 28(2), 592-636.

Mattila, A.S., Hanks, L., and Kim, E.E.K. (2010). The impact of company type and corporate social responsibility messaging on consumer perceptions. Journal of Financial Services Marketing, 15(2), 126-35.

McWilliams, A., and Siegel, D. (2001). Corporate social responsibility: A theory of the firm perspective. The Academy of Management Review, 26(1), 117-27.

Meister, J. (2012). Corporate social responsibility: A lever for employee attraction \& engagement. Forbes: Leadership, June 7, 2012. Accessed February 1, 2013 at http://www.forbes.com/sites/jeannemeister/2012/06/07/ corporate-social-responsibility-a-lever-for-employee-attraction-engagement/.

Melo, T., and Garrido-Morgado, A. (2012). Corporate reputation: A combination of social responsibility and industry. Corporate Social Responsibility and Environmental Management, 19, 11-31.

Menon, S., and Kahn, B.E. (2003). Corporate sponsorships of philanthropic activities: When do they impact perception of sponsor brand? Journal of Consumer Psychology, 13(3), 316-27.

MeritDirect (2013), Advertising Age active subscribers, Merit Direct, Inc., see http://adage.com/.

Meyer, J.W., Pope, S., and Isaacson, A. (2015). Legitimating the corporation in a world society. In K. Tsutsui and A. Lim (eds), Corporate Social Responsibility in a Globalizing World, pp. 27-73. Cambridge, UK: Cambridge University Press.

Mishra, S., and Modi, S.B. (2013). Positive and negative corporate social responsibility, financial leverage, and idiosyncratic risk. Journal of Business Ethics, 117(2), 431-48.

Mögele, B., and Tropp, J. (2010). The emergence of CSR as an advertising topic: A longitudinal study of German CSR advertisements. Journal of Marketing Communications, 16(3), 163-81.

Mohr, L.A., and Webb, D.J. (2005). The effects of corporate social responsibility and price on consumer responses. Journal of Consumer Affairs, 39(1), 121-47.

Muli, S. (2013). Sustainability rankings: Impacts on corporate sustainability. Master of Environmental Studies Capstone Projects. University of Pennsylvania.

Muller, A., and Kräussl, R. (2011). Doing good deeds in times of need: A strategic perspective on corporate disaster donations. Strategic Management Journal, 32(9), 911-29.

Navarro, P. (1988). Why do corporations give to charity? The Journal of Business, 61(1), 65-93.

Nelson, P. (1974). Advertising as information. Journal of Political Economy, 82(4), 729-54.

Nicholson, L. (2007). An investigation into the decision to communicate corporate social responsibility initiatives. Bachelor of Business thesis. Swinburne University of Technology. 
Nielsen. (2013). Consumers who care, Nielsen.com, June 8, 2013. Accessed November 11, 2017 at http://www. nielsen.com/us/en/insights/reports/2013/consumers-who-care.html.

Okoye, A. (2009). Theorising corporate social responsibility as an essentially contested concept: Is a definition necessary? Journal of Business Ethics, 89(4), 613-27.

O'Rourke, A. (2002). A new politics of engagement: Shareholder activism for corporate social responsibility. Paper at the 'For the Greening of Industry' Conference, June 23-26, Göteborg.

Parguel, B., Benoît-Moreau, F., and Larceneux, F. (2011). How sustainability ratings might deter 'greenwashing': A closer look at ethical corporate communication. Journal of Business Ethics, 102(1), 15-28.

Pomering, A., and Dolnicar, S. (2009). Assessing the prerequisite of successful CSR implementation: Are consumers aware of CSR initiatives? Journal of Business Ethics, 85(S2), 1-17.

Pope, S. (2015). Why firms participate in the global CSR initiatives, 2000-2010. In K. Tsutsui and A. Lim (eds), Corporate Social Responsibility in a Globalizing World, pp. 251-86. Cambridge, UK: Cambridge University Press.

Pope, S. (2016). What drives them to do good? A global meta-study of business leaders' CSR motivations. Stanford University Paper.

Pope, S., and Lim, A. (2017). International organizations as mobilizing structures: The world CSR associations and their disparate impacts on members' CSR practices, 2000-2014. Social Forces, 95(4), 1725-55.

Pope, S., and Meyer, J.W. (2015). The global corporate organization. Management and Organization Review, 11(2), 173-7.

Pope, S., and Meyer, J.W. (2016). Local variation in world society: Six characteristics of global diffusion. European Journal of Cultural and Political Sociology, 3, 280-305.

Pope, S., and Wæraas, A. (2016). CSR-washing is rare: A conceptual framework, literature review, and critique. Journal of Business Ethics, 137(1), 173-93.

Raub, S., and Blunschi, S. (2013). The power of meaningful work: How awareness of CSR initiatives fosters task significance and positive work outcomes in service employees. Cornell Hospitality Quarterly, 55(1), $10-18$.

Reid, E.M., and Toffel, M.W. (2009). Responding to public and private politics: Corporate disclosure of climate change strategies. Strategic Management Journal, 30(11), 1157-78.

Russo, A., and Tencati, A. (2008). Formal vs. informal CSR strategies: Evidence from Italian micro, small, medium-sized, and large firms. Journal of Business Ethics, 85(S2), 339-53.

Santilli, P.C. (1983). The informative and persuasive functions of advertising: A moral appraisal. Journal of Business Ethics, 2(1), 27-33.

Scalet, S., and Kelly, T.F. (2009). CSR rating agencies: What is their global impact? Journal of Business Ethics, 94(1), 69-88.

Servaes, H., and Tomayo, A. (2012). The impact of corporate social responsibility on firm value: The role of customer awareness. Management Science. Accessed November 11, 2017 at https://papers.ssrn.com/sol3/ papers.cfm?abstract_id=2116265\&rec $=1 \&$ srcabs $=1961971 \&$ alg $=1 \&$ pos $=6$.

Shabana, K.M., Buchholtz, A.K., and Carroll, A.B. (2016). The institutionalization of corporate social responsibility reporting. Business \& Society, 56(8), 1107-35.

Soederberg, S. (2007). Taming corporations or buttressing market-led development? A critical assessment of the global compact. Globalizations, 4(4), 500-513.

Soule, S.A. (2009). Contention and Corporate Social Responsibility. Cambridge, UK: Cambridge University Press.

Stanwick, P.A., and Stanwick, S.D. (1998). The relationship corporate social performance and organizational size, financial performance, and environmental performance: An empirical examination. Journal of Business Ethics, 17(2), 195-204.

Strangberg Consulting. (2013). Sustainable Supply Chain Survey 2013. Accessed November 11, 2017 at https:// corostrandberg.com/sustainable-supply-chain-survey-2013/.

Strike, V.M., Gao, J., and Bansal, P. (2006). Being good while being bad: Social responsibility and the international diversification of US firms. Journal of International Business Studies, 37(6), 850-62.

Tashman, P., and Rivera, J. (2010). Are members of business for social responsibility more socially responsible? The Policy Studies Journal, 38(3), 487-514.

Thérien, J., and Pouliot, V. (2006). The global compact: Shifting the politics of international development? Global Governance, 12, 55-75.

Tixier, M. (2003). Soft vs. hard approach in communicating on corporate social responsibility. Thunderbird International Business Review, 45, 71-91.

Turban, D.B., and Greening, D.W. (1997). Corporate social performance and organizational attractiveness to prospective employees. Academy of Management Journal, 40(3), 658-72.

Udayasankar, K. (2008). Corporate social responsibility and firm size. Journal of Business Ethics, 83, $167-75$.

Utting, P. (2000). UN-business partnerships: Whose agenda counts? Paper presented at the 'Partnerships for Developing or Privatization of the Multilateral System?' Conference, Oslo, 8 December 2000. 


\section{Research handbook of finance and sustainability}

Varadarajan, R., and Menon, A. (1988). Cause-related marketing: A coalignment corporate strategy and corporate philanthropy. Journal of Marketing, 52(3), 58-74.

Vermeir, I., and Verbeke, W. (2006). Sustainable food consumption: Exploring the consumer 'attitude-behavioral intention' gap. Journal of Agricultural and Environmental Ethics, 19, 169-94.

Visser, W., Matten, D., Pohl, M., and Tolhurst, N. (2010). The A to Z of Corporate Social Responsibility. Chichester, UK: Wiley.

Vogel, D. (2010). The private regulation of global corporate conduct. Business \& Society, 49(3), 68-87.

Waddock, S., and Graves, S.B. (1997). The corporate social performance-financial performance link. Strategic Management Journal, 18(4), 303-19.

Wagner, M. (2010). The role of corporate sustainability performance for economic performance: A firm-level analysis of moderation effects. Ecological Economics, 69(7), 1553-60.

Walls, J.L., Berrone, P., and Phan, P.H. (2012). Corporate governance and environmental performance: Is there really a link? Strategic Management Journal, 51(2), 315-34.

Wang, A. (2009). Advertising disclosures and CSR practices of credit card issuers. Management Research News, 32(12), 1177-91.

World Economic Forum, and International Business Leaders Forum. (2003). Values and Value: Communicating the Strategic Importance of Corporate Citizenship to Investors. Accessed November 11, 2017 at https://sites. hks.harvard.edu/m-rcbg/CSRI/publications/other_3_nelson_values_and_value.pdf.

Zhang, R., Zhu, J., Yue, H., and Zhu, C. (2009). Corporate philanthropic giving, advertising intensity, and industry competition level. Journal of Business Ethics, 94(1), 39-52.

Zhao, G. (2012). CSR and its impact on consumer behavior. Advanced Level thesis. Jönköping International Business School. 